\title{
Six decades of glacier mass-balance observations: a review of the worldwide monitoring network
}

\author{
M. ZEMP, M. HOELZLE, W. HAEBERLI \\ World Glacier Monitoring Service, University of Zürich, Winterthurerstrasse 190, CH-8057 Zürich Switzerland \\ E-mail: michael.zemp@geo.uzh.ch
}

\begin{abstract}
Glacier mass balance is the direct and undelayed response to atmospheric conditions and hence is among the essential variables required for climate system monitoring. It has been recognized as the largest non-steric contributor to the present rise in sea level. Six decades of annual mass-balance data have been compiled and made easily available by the World Glacier Monitoring Service and its predecessor organizations. In total, there have been 3480 annual mass-balance measurements reported from 228 glaciers around the globe. However, the present dataset is strongly biased towards the Northern Hemisphere and Europe and there are only 30 'reference' glaciers that have uninterrupted series going back to 1976. The available data from the six decades indicate a strong ice loss as early as the 1940s and 1950s followed by a moderate mass loss until the end of the 1970 s and a subsequent acceleration that has lasted until now, culminating in a mean overall ice loss of over $20 \mathrm{~m}$ w.e. for the period 1946-2006. In view of the discrepancy between the relevance of glacier mass-balance data and the shortcomings of the available dataset it is strongly recommended to: (1) continue the long-term measurements; (2) resume interrupted long-term data series; (3) replace vanishing glaciers by earlystarting replacement observations; (4) extend the monitoring network to strategically important regions; (5) validate, calibrate and accordingly flag field measurements with geodetic methods; and (6) make systematic use of remote sensing and geo-informatics for assessment of the representativeness of the available data series for their entire mountain range and for the extrapolation to regions without in situ observations; and (7) make all these data and related meta-information available.
\end{abstract}

\section{INTRODUCTION}

The World Glacier Monitoring Service (WGMS) collects and publishes mass-balance data of glaciers obtained by direct glaciological and geodetic methods as a contribution to the Global Terrestrial Network for Glaciers (GTN-G) which is part of the Global Climate/Terrestrial Observing Systems (GCOS/GTOS; GCOS 2004). The GTN-G monitoring strategy uses glacier observations in a system of tiers (cf. Haeberli and others, 2000; Haeberli, 2004). These tiers include extensive glacier mass-balance measurements within major climatic zones for improved process understanding and the calibration of numerical models (tier 2), as well as for the determination of regional volume changes within major mountain ranges using cost-saving methodologies (tier 3). Glacier-front variation and global inventories are further components of the monitoring strategy but are not discussed here. First surveys of accumulation and ablation of snow, firn and ice at individual stakes date back to the end of the 19th century and beginning of the 20th century, for example at Rhone glacier (Mercanton, 1916) and Silvretta glacier (Huss and others, 2008a). Annual glacier massbalance measurements made by the direct glaciological method (cf. Østrem and Stanley, 1969; Østrem and Brugman, 1991), based on an extensive net of ablation stakes, snow pits and snow probing, were initiated in 1945 at Storglaciären, Sweden (Holmlund and others, 2005). Today, six decades of annual (and partially seasonal) mass-balance data are readily available from the WGMS and have been analyzed in detail by Dyurgerov (2002) and widely used for studies of glacier changes (e.g. Braithwaite, 2002; Dyurgerov and Meier, 2005) and related questions from hydrology (e.g. Braun and others, 2000), climate change (e.g. Oerle- mans and Fortuin, 1992; Francou and others, 2003; Ohmura, 2006) or sea-level variation studies (e.g. Kaser and others, 2006; Raper and Braithwaite, 2006; Meier and others, 2007). However, due to the specific foci of these works, a sound and integrative discussion of the basic dataset and related issues is often missed out. Here we aim to give a review of the present monitoring network, a spatiotemporal analysis of the available data and discuss important issues related to the monitoring and interpretation of glacier mass-balance data.

\section{AVAILABLE MASS-BALANCE DATA}

The WGMS collects mass-balance data of glaciers annually from the preceding year through its collaboration network of national correspondents and principal investigators. This 1 year retention period allows the investigators time to properly analyze and publish their data before making them available to the scientific community and the wider public. Preliminary data are published annually on the WGMS website (www.wgms.ch) and every 2 years in the Glacier Mass Balance Bulletins (WGMS, 2007, and earlier issues) as well as every 5 years, in full detail, in the Fluctuations of Glaciers (WGMS, 2008a, and earlier issues). All data are available digitally on request and free of charge. We aim to collect seasonal and annual mass-balance data that are measured according to the direct glaciological method (cf. Østrem and Stanley, 1969; Østrem and Brugman, 1991), i.e. based on a network of ablation stakes and snow pits distributed over the entire glacier, and inter-/extrapolated to the total area of the (same) glacier independently of meteorological or hydrological measurements. Ideally, these mass-balance measurements determined annually are 


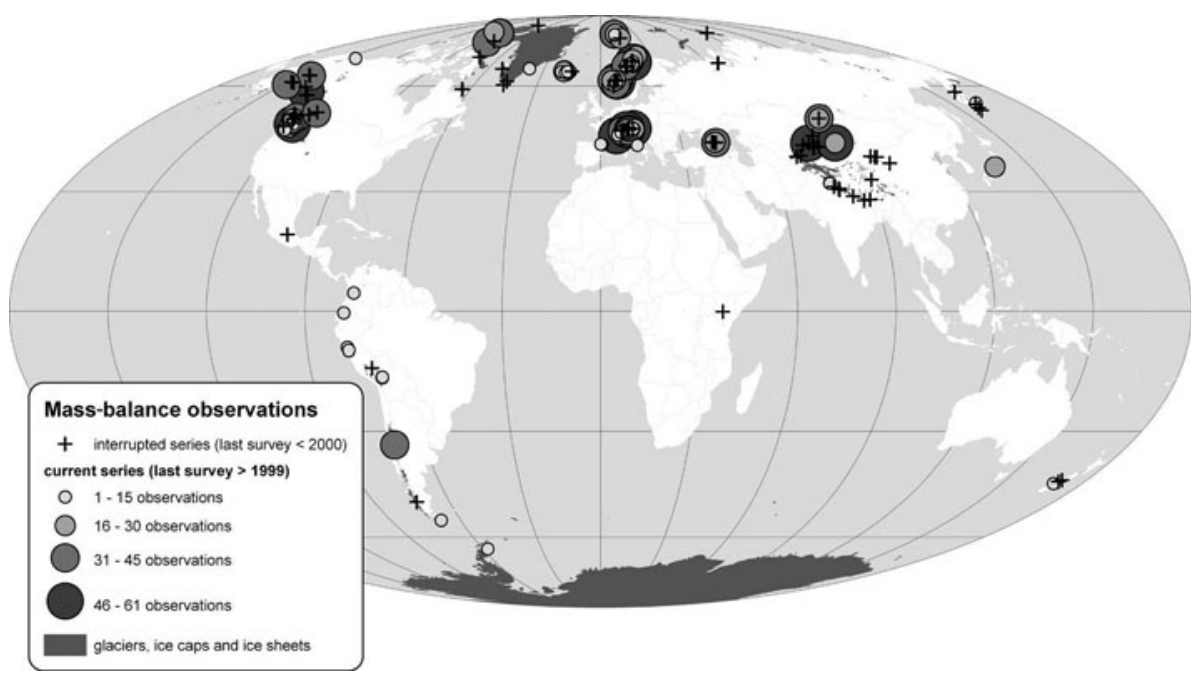

Fig. 1. Global overview of available mass-balance measurements from 1946 to 2006 . The current series, sized according to the number of observations, and interrupted programmes are plotted over the global distribution of glaciers, ice caps and the two ice sheets. Note that the data point in Japan refers to the Hamaguri Yuki snowfield. Data sources: mass-balance data from the WGMS, outlines of countries and ice cover from the Environmental Systems Research Institute's Digital Chart of the World.

combined with decadal volume-change assessments from geodetic surveys to reduce method-dependent uncertainties and systematic errors.

For the period 1946-2005, there are 3385 annual massbalance results from 228 glaciers available through the WGMS (Fig. 1). Additional information on mass-balance vs altitude intervals has been reported for $45 \%$ of the annual observations and for $56 \%$ of the glaciers. A derived equilibrium-line altitude (ELA) and accumulation-area ratio (AAR) are available for $73 \%$ and $82 \%$ of the annual values and data series, respectively. Seasonal mass balances have been submitted for $45 \%$ of the observation years and for $63 \%$ of the glaciers. From the 228 available data series, 120 provide information from the 21 st century whereas the remaining data series were interrupted in the past century. The average period of observations per series is 15 years, and 39 glaciers have more than 30 years of measurements. For the hydrological year 2006, preliminary mass-balance data

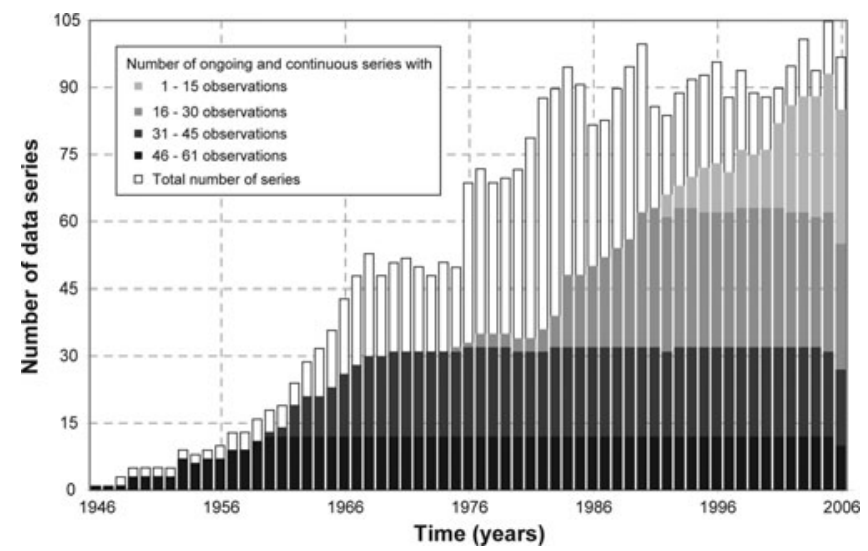

Fig. 2. Temporal overview of available mass-balance series from 1946 to 2006. The total number of reported data series per year is overlaid with the number of ongoing (i.e. last survey after 2003) and continuous (i.e. number of data gaps $<20 \%$ of observation years) measurement programmes, shaded according to the number of observations per series. Source: data from the WGMS. have been reported from 97 glaciers. A temporal overview of the number of data series reported to the WGMS is given in Figure 2. The total number of series is shown together with the data series that are ongoing, continuous and consist of up to $15,30,45$ and 61 observation years. Of the 228 data series, there are just 31 continuous measurement programmes reaching back to 1970, and only 12 back to 1960. Of these glaciers, the Glacier Mass Balance Bulletin (WGMS, 2007) lists a set of 30 'reference' glaciers with continuous measurement programmes back to 1976 and earlier (see Appendix).

\section{MASS-BALANCE SERIES VS THE GLOBAL GLACIER DISTRIBUTION}

About $90 \%$ of the mass-balance series come from the Northern Hemisphere and about 40\% from Europe. An overview of the available mass-balance series in comparison with the global distribution of glaciers is given in Table 1. Most with the longest time series are found in the European Alps and Scandinavia, followed by North America and High Mountain Asia, with the earliest observations in the 1940s and 1950s, respectively. In the Canadian Arctic Archipelago and in High Mountain Asia, more than two-thirds of the series were interrupted in the last century. The only longterm observation series from the tropics, at Lewis Glacier (1979-96) on Mount Kenya, results in the high average observation length of the region class 'Africa, New Guinea, Irian Jaya'. Northern Asia and Siberia, South America and the large ice masses around the two ice sheets in Greenland and Antarctica with few and only short-term data series are strongly underrepresented within the network (in respect of their ice cover).

The size and elevation distributions of the glaciers with available mass-balance observations and the glaciers with detailed information in the World Glacier Inventory (WGI; WGMS, 1989) are given in Tables 2 and 3, respectively. The total area covered by the 228 glaciers with mass-balance series is about $10000 \mathrm{~km}^{2}$. More than $75 \%$ of the glaciers have an area of $0.1-10.0 \mathrm{~km}^{2}$, covering $2.5 \%$ of the total ice 
Table 1. Global distribution of glaciers and of mass-balance series. The ice cover of 12 macro-regions is listed with an overview of available mass-balance series including the number of mass-balance programmes, recent observation series and 'reference' glaciers, as well as the first/last survey years and the average duration of the observation series. Information about the ice cover comes from Dyurgerov and Meier (2005) which is based mainly on WGMS (1989). Mass-balance data come from the WGMS

\begin{tabular}{|c|c|c|c|c|c|c|c|}
\hline Macro-region & $\begin{array}{l}\text { Area } \\
\mathrm{km}^{2}\end{array}$ & $\begin{array}{l}\text { Mass-balance } \\
\text { series }\end{array}$ & $\begin{array}{l}\text { Observations } \\
>1999\end{array}$ & $\begin{array}{l}\text { Reference } \\
\text { glaciers }\end{array}$ & First survey & Last survey & $\begin{array}{l}\text { Average observation } \\
\text { duration }\end{array}$ \\
\hline Africa, New Guinea, Irian Jaya & 9 & 1 & 0 & 0 & 1979 & 1996 & 18.0 \\
\hline New Zealand & 1160 & 1 & 1 & 0 & 2005 & 2006 & 2.0 \\
\hline European Alps, Pyrenees, Caucasus & 3785 & 43 & 29 & 10 & 1948 & 2006 & 20.2 \\
\hline South America & 25000 & 11 & 9 & 1 & 1976 & 2006 & 8.6 \\
\hline Scandinavia, Iceland, West Arctic Islands & 50809 & 59 & 40 & 10 & 1946 & 2006 & 15.7 \\
\hline Northern Asia, Siberia, East Arctic Islands & 59279 & 9 & 1 & 0 & 1973 & 2000 & 6.0 \\
\hline Around Greenland & 76200 & 5 & 1 & 0 & 1979 & 2006 & 3.5 \\
\hline High Mountain Asia, Japan & 116180 & 40 & 10 & 5 & 1957 & 2006 & 15.0 \\
\hline North America (US+CD+MX), Alaska & 124260 & 45 & 24 & 4 & 1953 & 2006 & 16.3 \\
\hline Canadian Arctic Archipelago & 151433 & 13 & 4 & 0 & 1960 & 2006 & 13.3 \\
\hline Around Antarctica & 169000 & 1 & 1 & 0 & 2002 & 2006 & 5.0 \\
\hline Global & 784115 & 228 & 120 & 30 & 1948 & 2006 & 15.3 \\
\hline
\end{tabular}

cover with mass-balance observations. About $90 \%$ of this ice cover comes from the 15 glaciers which are $>100 \mathrm{~km}^{2}$. The elevation of the terminus of $33 \%, 60 \%$ and $80 \%$ of these glaciers is below 1000, 2000 and 3000 m a.s.I., respectively. The glaciers of the WGI, with detailed area information, cover overall about $180000 \mathrm{~km}^{2}$ which corresponds to about $23 \%$ of the estimated global glacier cover (Dyurgerov and Meier, 2005). About $80 \%$ of these glaciers are $<1 \mathrm{~km}^{2}$ and represent $7.5 \%$ of the inventoried ice cover, whereas $50 \%$ of this ice cover comes from the 235 glaciers $>100 \mathrm{~km}^{2}$. Half of the inventoried glaciers end between 3000 and $5000 \mathrm{~m}$ a.s.l., and less than $10 \%$ reach below $1000 \mathrm{~m}$ a.s.l.

\section{SPATIO-TEMPORAL ANALYSIS OF GLOBAL AND REGIONAL GLACIER MASS CHANGES}

The 30 'reference' glaciers (see WGMS, 2007) with (almost) continuous measurements since 1976 show an (arithmetic) average annual mass loss of $0.58 \mathrm{mw}$.e. for the decade 1996-2005, which is more than twice the loss rate for the period 1986-95 (0.25 m w.e.), and more than four times the rate for the period $1976-85$ (0.14 m w.e.). The preliminary value of $-1.30 \mathrm{~m}$ w.e. for 2006 (based on so far reported values from 27 reference glaciers) seems likely to become a new record loss surpassing the mass-balance values of the years 2003 (-1.24 mw.e.), 2004 (-0.74 mw.e.) and 1998 $(-0.71 \mathrm{~m}$ w.e.). The apparent advantage of analyzing only continuous mass-balance series comes with the disadvantage of having to deal with a small sample size and shorter data series. As a consequence, the available mass-balance values can be averaged annually, disregarding the completeness and length of the time series, but it is necessary to accept all the problems related to moving sample size (Ohmura, 2004; Cogley, 2005; Dyurgerov and Meier, 2005). A third approach takes into account that the mean of all glaciers is strongly biased by the large proportion of Alpine and Scandinavian glaciers and, hence, calculates the annual mass balance from the (arithmetic) averaged regional mean values (cf. Haeberli and others, 2007). Other ways to correct for the spatial bias of the data are to use regional averages which are weighted by the corresponding glacier area or to apply polynomial spatial interpolation (e.g. Cogley, 2005). Figure 3 shows the cumulative mean (annual) mass balances of: (1) the 30 reference glaciers (and the subsample before 1977); (2) all available glaciers; (3) all available glaciers excluding the reference glaciers; (4) the (subsample of) averages of the 12 macro-regions (Table 1); and (5) the (subsample of) area-weighted averages of the 12 macroregions (Table 1). The samples used in approaches (1) and (3) are entirely independent; however, (2), (4) and (5) contain the sample from (1). From 1946 to 2006 (i.e. 61 years), the mean of all five approaches shows a cumulative ice loss of $21.2 \mathrm{~m}$ w.e., corresponding to an average annual ice loss of $0.35 \mathrm{~m}$ w.e. After six decades the difference between the five approaches, i.e. the range between (3) and (5), is $5.14 \mathrm{~m}$ w.e. This corresponds to an annual difference of $0.08 \mathrm{~m}$ w.e. and is in the same order of magnitude as the mean annual standard errors of the approaches (e.g. (1): 0.19 mw.e.; (2) and (3): $0.12 \mathrm{~m}$ w.e.).

Table 2. Size distribution of glaciers. The number and area of glaciers with available mass-balance observation (MB) and detailed inventory (WGI) data are listed according to their size class. Data from the WGMS

\begin{tabular}{|c|c|c|c|c|}
\hline \multirow{3}{*}{$\begin{array}{l}\text { Size class } \\
\mathrm{km}^{2}\end{array}$} & \multicolumn{2}{|c|}{ Number of glaciers } & \multicolumn{2}{|c|}{ Area of glaciers } \\
\hline & MB & WGI & MB & WGI \\
\hline & & & & \\
\hline$<0.1$ & $4 \%$ & $23 \%$ & $0 \%$ & $0 \%$ \\
\hline$\geq 0.1$ and $<1$ & $45 \%$ & $56 \%$ & $1 \%$ & $7 \%$ \\
\hline$\geq 1$ and $<10$ & $32 \%$ & $18 \%$ & $2 \%$ & $19 \%$ \\
\hline$\geq 10$ and $<100$ & $13 \%$ & $2 \%$ & $8 \%$ & $24 \%$ \\
\hline $\begin{array}{l}\geq 100 \text { and } \\
<1000\end{array}$ & $5 \%$ & $1 \%$ & $44 \%$ & $31 \%$ \\
\hline$\geq 1000$ & $1 \%$ & $0 \%$ & $45 \%$ & $19 \%$ \\
\hline Total & 228 & 67737 & $10087 \mathrm{~km}^{2}$ & $179979 \mathrm{~km}^{2}$ \\
\hline
\end{tabular}


Table 3. Elevation distribution of glacier termini. The number of glaciers with available mass-balance observation $(\mathrm{MB})$ and detailed inventory (WGI) data are listed according to the elevation class of the ice front. Data from the WGMS
Elevation class

Number of glaciers
WGI

ma.s.l.
$>5999$

5000-5999

4000-4999

3000-3999

2000-2999

1000-1999

$<1000$

Total

$$
\begin{gathered}
0 \% \\
1 \% \\
9 \% \\
12 \% \\
20 \% \\
26 \% \\
32 \%
\end{gathered}
$$

228

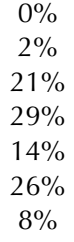

63189
Regional and individual cumulative mass-balance curves

have been shown and discussed in detail, for example by Kaser and others (2006, and references therein) and WGMS (2007). Here, we dissolve the global glacier mass balances, using approach (2), in six macro-regions and six decades (Fig. $4 a-f)$. In addition to the global and regional mass balance, the standard deviation and the number of available observations are given in order to provide a measure for the variance and the observation density, respectively. For the first three decades (1946-75), mass-balance measurements are available only for latitudes higher than $30^{\circ} \mathrm{N}$. Later, information becomes available from the regions between $30^{\circ} \mathrm{N}$ and $30^{\circ} \mathrm{S}$. Latitudes below $30^{\circ} \mathrm{S}$ are covered with observations from South America after 1976, and from the northeastern side of the Antarctic Peninsula and New Zealand in the last decade. The regional data samples higher than $30^{\circ} \mathrm{N}$ consist of more than 100 observations per decade after 1976, whereas the six regions south of that exceed ten observations only in the case of South America in the last decade and, hence, are to be considered of limited significance.

In the decade 1946-55, observations of the five glaciers in the European Alps and two glaciers in Scandinavia indicate a mass loss of more than $0.4 \mathrm{~m}$ w.e., whereas the mean of the two glaciers in North America features a zero balance over the last 3 years of that decade. In the following two decades (1956-75), North America, Europe and Northern Asia show a moderate ice loss, with a mean annual change of -0.10 to -0.25 m w.e. After 1976, the decadal mass losses increase in North America and Northern Asia to mean annual mass balances of -0.65 and -0.43 mw.e., respectively, in the last decade. The decadal mean balances in Europe remain moderately negative between 1976 and 1995 , due to the temporal regain in mass of some glaciers, and become strongly negative $(-0.72 \mathrm{mw.e.})$ in the last decade. In South America, positive and close to steady-state balances are reported in the third decade (1976-85) from Quelccaya (PE) and Echaurren Norte $(\mathrm{CL})$, respectively, followed by two decades of average ice losses with values between -0.26 and -0.90 mw.e. from a sample of 12 glaciers (including four observations from Ventorillo (MX)). In Africa, negative mass balances have been reported from Lewis Glacier on Mount Kenya with observations between

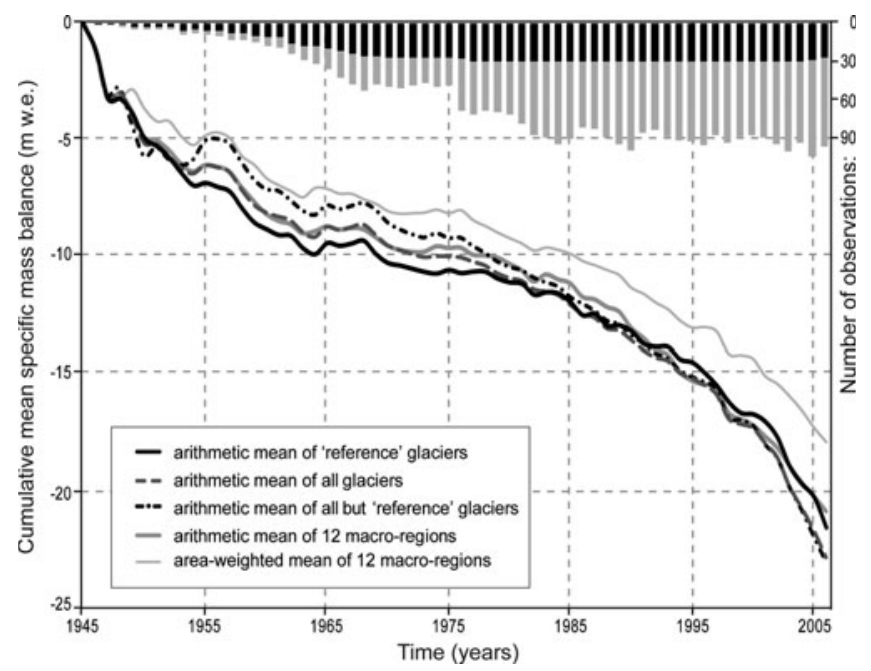

Fig. 3. Global glacier mass changes from 1945 to 2006. The cumulative mean specific mass balance (left $y$ axis) of the reference glaciers and of four different sampling/averaging approaches (see text) are shown together with the number of available observations (right $y$ axis) from reference (black) and other (grey) glaciers. Source: data from the WGMS.

1979 and 1996. The three negative decadal balances of Southern Asia come from 11 observations from AX010 and Rikha Samba, Nepal Himalaya, and from Changmekhangpu, Sikkim Himalaya. Furthermore, the average mass loss of Bahía del Diablo on Vega Island, Antarctica, (-0.25 m w.e.) and the 1 year gain of Brewster (NZ) show up in the last decade.

\section{DISCUSSION}

\section{Available dataset and 'reference' glacier concept}

Unlike meteorological data, which are mainly measured, collected and made available through governmental agencies (GCOS, 2003), glacier mass-balance observations are usually carried out within scientific projects, collected within a cooperation network, and made available by the WGMS. As a consequence, the data collection runs with a very low funding level and depends fully on the cooperativeness of the individual investigators. An exception is Norway where for decades the majority of mass-balance observation programmes (over 40 series) have been run and made available by the Norwegian Water Resources and Energy Directorate. At first glance, the available massbalance observations seem to be well distributed over the globe. However, looking at the length and continuity, or lack thereof, of the time series it is apparent that the observation network is strongly overrepresented by glaciers located in Europe and North America. Unfortunately, the regions hosting large proportions of the glacier cover of the Earth (e.g. the Canadian Archipelago, Patagonia, the Arctic Islands and the ice bodies around the two ice sheets in Greenland and Antarctica) are greatly underrepresented or even lack any long-term data series. In Asia a large number of observation series have been started but the vast majority were interrupted in the 1980s and 1990s.

With regard to the limited dataset, it is particularly unfortunate that data on mass balance vs altitude have been 


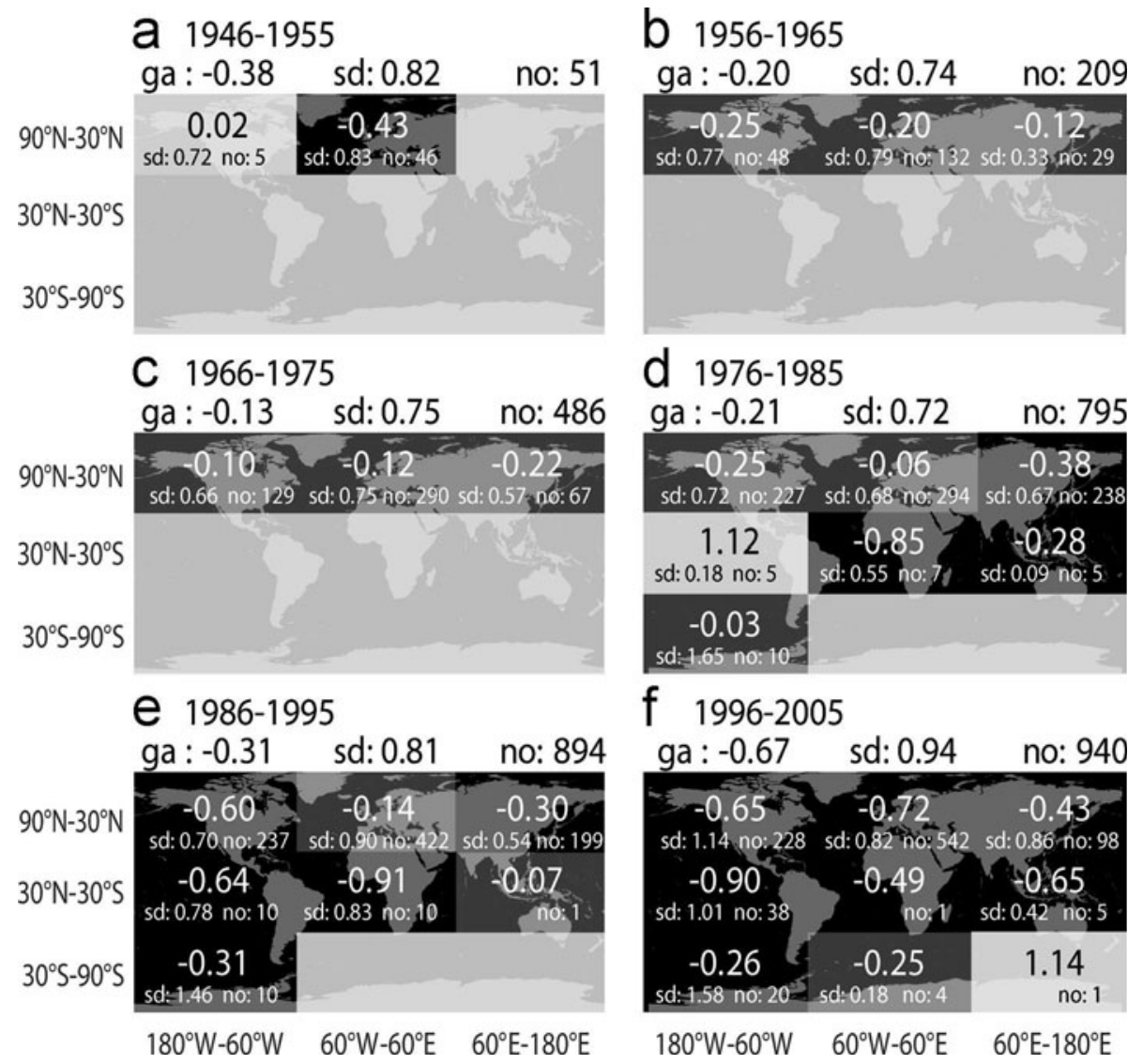

Fig. 4. Spatio-temporal overview of glacier mass changes. The average annual mass balance for nine spatial sectors of the globe is shown for the six decades between 1946 and $2005(a-f)$. Sectors with observations are highlighted according to the mean annual mass balance (in $\mathrm{m}$ w.e.), with positive balances in white, ice losses up to $0.25 \mathrm{~m}$ w.e. in dark grey and ice losses greater than this in black. For each decade the global average (ga), standard deviations (sd) and number of observations (no) are given. Source: figure modified from WGMS (2008b), based on data from the WGMS.

reported for only $45 \%$ of the annual measurements and ELA AAR for only $73 \%$. The seasonal balances were measured at $63 \%$ of the glaciers. Mass balance vs altitude and ELA/AAR can, at least in principle, be derived from the existing raw data and would provide valuable information about, for example, mass-balance gradients (e.g. Dyurgerov and Dwyer, 2001), mass turnover (e.g. Dyurgerov, 2002), the glacier climate regime (e.g. Hoelzle and others, 2003) and climate sensitivity (e.g. Oerlemans and Fortuin, 1992). In order to improve the available seasonal dataset, the annual observation programmes need to be extended with seasonal field surveys, although the in situ determination of the winter/wet-season accumulation might be a major challenge. Once available, these data would provide insight into the processes behind the glacier fluctuations (e.g. Dyurgerov and Meier, 1999; Schöner and others, 2000; Ohmura, 2006) and would be of great value for model validation (e.g. Oerlemans, 2001). The observation and standardized compilation of further parameters such as temperature and precipitation at the ELA, ice/firn temperatures or the remaining mean/maximum ice thickness would be of great value for many scientific questions, especially in view of the fast changes in nature.

Trend analyses ideally are based on long-term measurement series. It is for that purpose that the WGMS has introduced the concept of 'reference' glaciers. A massbalance observation programme is considered to be a 'reference' series if it is ongoing, continuous and long-term (see Fig. 2), with reliable reporting of data and metainformation. At present, a set of 30 reference glaciers in nine mountain ranges (in five of the macro-regions; see Table 1) are listed in the Glacier Mass Balance Bulletin series (WGMS, 2007) with (almost) continuous observations since 1976, and for 11 of the reference glaciers observations reach back to 1960 or earlier (see Appendix). The set of reference glaciers is reviewed after each call-for-data and it will help to support the continuation of these unique data series. Further glaciers that could be considered next as reference glaciers include Baby and White (Canadian High Arctic), Peyto (Canadian Rocky Mountains), Helm (Canadian Coast Mountains) and Lemon Creek (US Coast Range).

\section{Uncertainties}

Data provided by the WGMS, but also in general, are subject to errors and inaccuracies and, hence, have to be qualitychecked against the related literature before being used in further analysis. The measurement and calculation of mass balances contain various sources of systematic and random errors that include: the accuracy of stake readings, snow probing and snow/firn density measurements (Østrem and Brugman, 1991; Jansson, 1999; Østrem and Haakensen, 1999), the distribution of the stake and pit network (Lliboutry, 1974; Cogley, 1999; Fountain and Vecchia, 1999), the method used to interpolate between the measurement points 
(Østrem and Brugman, 1991; Kaser and others, 1996; Funk and others, 1997; Hock and Jensen, 1999), the extrapolation for unprobed areas such as crevasse (Karlén, 1965; Jannson, 1999) or debris-covered zones (Nakawo and Rana, 1999, Nakawa and others, 2000), special problems related to internal accumulation (Rabus and Echelmeyer, 1998) and calving (Arendt and others, 2002; Rignot and others, 2003; O'Neel and others, 2005), as well as any changes in the glacier area that are usually not subject to annual measurement (Elsberg and others, 2001). Generally, the accuracy of the results from the summer balance and the ablation area exceeds that of the results from the winter balance and the accumulation zone, as the ablation processes spatially correlate much better than the snow accumulation (Jansson, 1999; Kuhn and others, 1999). The dimensions of the various errors are glacier-specific, and their propagation is hard to quantify. Typical estimates of the annual mass-balance accuracy range lie between $0.1 \mathrm{~m}$ w.e. (Jansson, 1999) and 0.6 mw.e. (Funk and others, 1997). Further errors are introduced when comparing mass balances derived from different measurement systems (stratigraphic vs fixed-date systems) or from different hemispheres (i.e. the hydrological years of the two hemispheres are shifted by half a year).

In contrast to the in situ point measurements based on a changing reference (i.e. the previous year's summer surface), geodetic methods have the advantage of providing volume changes over the entire glacier based on a non-changing reference (i.e. the surrounding bedrock), but encounter some problems with (fresh) snow in the accumulation area and density assumption for snow, firn and ice (Krimmel, 1999). A combination of the direct glaciological method with decadal geodetic methods has proven to be an appropriate way to detect systematic biases (e.g. Jansson, 1999; Krimmel, 1999; Kuhn and others, 1999; Bauder and others,

2007). Several studies have shown that other remotesensing methods are also useful for determining glacier volume changes over longer periods, for example those based on airborne laser altimetry (Arendt and others, 2002) or the differencing of digital elevation models using SPOT5 (Système Probatoire pour l'Observation de la Terre) (Berthier and others, 2007), SRTM (Shuttle Radar Topography Mission) (Rignot and others, 2003; Larsen and others, 2007; Schiefer and others, 2007) or ASTER (Advanced Spaceborne Thermal Emission and Reflection Radiometer) and its optical stereo (Kääb, 2007). Differencing of digital elevation models from space-borne sensors is, at present, no replacement for such validation purposes, as the resolution and quality is still too low. However, it can already be used to assess the representativeness of available field measurements with respect to long-term glacier volume changes over large areas (e.g. Kääb, 2008).

Given the present state of knowledge, the manifold sources of errors, and the often missing meta-information, it is not possible to quantify the overall error of the available mass-balance data. As an objective measure of uncertainty we, hence, estimate the confidence interval of the herepresented global dataset to be in the magnitude of two standard errors of the reported annual mass-balance data, i.e. between 0.25 and $0.5 \mathrm{~m}$ w.e. but increasing with small sample sizes. With an average annual standard deviation of about $0.7 \mathrm{~m}$ w.e., the annual signal of the mean mass balances is smaller than the regional variability. However, the change of the cumulative mean mass balances over extended periods is far beyond the estimated uncertainty and, hence, significant. In order to reduce, better understand and quantify these uncertainties, we reiterate the recommendation to validate and calibrate systematically the massbalance data derived from annual/seasonal field observations with decadal mass/volume changes as assessed from geodetic methods, and to submit also the corresponding meta-information. It is one of the major shortcomings of the available datasets that this information is often missing and, as a consequence, it is difficult to reconstruct whether a mass-balance series is geodetically calibrated or not.

\section{Global and regional glacier changes}

The global average cumulative mass balance indicates a strong mass loss in the first decade after the start of the measurements in 1946 (for Europe), slowing down in the second decade (1956-65; based on observations above $30^{\circ} \mathrm{N}$ only), followed by a moderate ice loss between 1966 and 1985 (with data from the Southern Hemisphere only since 1976) and a subsequent acceleration until the present (2006). Over the six decades the global average ice loss has cumulated to about $21 \mathrm{~m}$ w.e., or an average mass balance of $-0.35 \mathrm{~m}$ w.e. $\mathrm{a}^{-1}$, a dramatic ice loss compared with the global average ice thickness which is estimated (by dividing volume by area) to be between $100 \mathrm{~m}$ (Solomon and others, 2007) and about $180 \mathrm{~m}$ (personal communication from A. Ohmura, 2008). The vast ice loss since the mid-20th century has already led to the disintegration of many glaciers within the observation network, including Lower Curties and Columbia 2057 (US), Chacaltaya (BO), Carèser (IT), Lewis $(\mathrm{KE})$ and Urumqihe $(\mathrm{CN})$, and presents one of the major challenges for glacier monitoring in the 21 st century.

The cumulative mass loss is in the same order for all the sample/methods used for averaging. These methods are: 30 reference glaciers (and subsamples before 1976), all but the reference glaciers, all glaciers, arithmetic and area-weighted average of the regions. In addition, the global result corresponds well with the findings of several approaches as summarized by Kaser and others (2006) and published in Solomon and others (2007). They state an average annual ice loss of $0.283 \mathrm{~m}$ w.e. between 1961 and 2004 (in this study, sampling approach (2) gave $0.286 \mathrm{mw}$.e.). This is not surprising, as both approaches are based mainly on the dataset provided by the WGMS, but Kaser and others (2006) extended about 70 data series which have either not been reported to the WGMS or had to be rejected due to insufficient data quality or to their dependence on hydrological/meteorological measurements. For the last three decades (1976-2006) the strong cumulative changes calculated from a sample of 60-100 glaciers from 8 of the 12 glacierized macro-regions can be considered as representative of the global mass-balance signal, as the mass-balance variability in time is spatially correlated over distances of several hundred kilometres (Letréguilly and Reynaud, 1990; Cogley and Adams, 1998). Some reservation has to be made because of the lack of data series for the glaciers around Greenland and Antarctica as well as in New Zealand, and because the sample of glaciers with mass-balance observations might not be representative, with respect to characteristics (e.g. tidewater, debris cover), ice temperature and hypsometry, of the ice bodies that are major (potential) contributors to sea-level change. Going further back in time, the average is based only on observations from North America, Europe and Asia, increasingly dominated by the sample from Europe. Together with the less pronounced 
trends, the 'global' average mass balance from this small and regionally biased sample might not be representative anymore for the other regions. Approaches using regional (areaweighted) averaging might reduce this bias but cannot completely overcome the lack of observations.

The regional cumulative mass changes can be considered to be a good first-order index for the glacier changes in these areas over the corresponding period. However, further analysis might have to resample the series according to the focus of the study and have to consider the glacial characteristics of the different geographical regions (Fountain and Vecchia, 1999): mass-balance variability of temperate alpine glaciers in the Northern Hemisphere is mainly driven by accumulation and ablation during winter and summer seasons, respectively (Kuhn and others, 1999). This is not valid for low-latitude glaciers where ablation occurs throughout the year and multiple accumulation seasons exist (Kaser and Osmaston, 2002), monsoonal glaciers of the Himalaya where the accumulation and ablation seasons occur at about the same time (Ageta and Fujita, 1996), and high-altitude and polar glaciers where any season can be the accumulation season (Chinn, 1985). However, annual/net mass balances integrate these seasonal complexities and as such might not be relevant for some analysis. Strongly diverse mass-balance characteristics also exist between glaciers under dry-continental conditions and in maritime regions. The former can be found in northern Alaska, Arctic Canada, sub-Arctic Russia, parts of the Andes near the Atacama Desert and in many central Asian mountain chains. They show low mass turnover, equilibrium lines at high altitudes and firn/ice well below melting temperatures. The latter, glaciers in maritime regions, are found in Patagonia, Iceland, southeast Alaska, as well as in the coastal parts of Norway and New Zealand, and show high mass turnover, low equilibrium lines and firn/ice at melting temperatures (Shumskiy, 1964; Ohmura and others, 1992; Haeberli and Burn, 2002).

For a sound analysis of global or regional glacier changes, results from the valuable but small sample of mass-balance measurements have to be complemented with other glacier observations, such as front variation measurements (available for about 1700 glaciers worldwide; WGMS, 2008, and earlier issues) or investigations of the glacier retreat from the trimlines of the Little Ice Age which can be found around the globe (Grove, 2004). Examples for such integrative analysis for entire mountain ranges are given by Molnia (2007) for Alaska, by Casassa and others (2007) for the Andean glaciers, by Kaser and Osmaston (2002) for tropical glaciers, by Andreassen and others (2005) for Norway, by Zemp and others (2007b) for the European Alps, by Kotlyakov (2006) for Russia, and by Chinn (2001) for New Zealand, as well as by Hoelzle and others (2003), Grove (2004), Zemp and others (2007a), and WGMS (2008b) for a global overview.

\section{Glacier mass balance as a climate proxy}

Glacier mass changes are used widely as a climate proxy in many environmental and climate change assessment reports (e.g. Solomon and others, 2007). The mass change of glaciers, which are not influenced by thick debris covers, calving or 'surge' instabilities, is the direct, undelayed reaction of a glacier to climatic forcing. The mass-balance variability in time is well correlated spatially over larger distances (Letréguilly and Reynaud, 1990; Cogley and
Adams, 1998) and with climatic parameters such as (seasonal) air temperature, precipitation and sunshine duration (Lliboutry, 1974; Schöner and others, 2000). However, the glacier mass-balance change provides an integrative climatic signal, and the quantitative attribution of the forcing to individual meteorological parameters is not straightforward. The energy and mass balance at the glacier surface is influenced by changes in atmospheric conditions (solar radiation, air temperature, precipitation, wind, cloudiness, etc.). Air temperature thereby plays a predominant role, as it is related to the radiation balance, turbulent heat exchange and solid/liquid precipitation ratio (Kuhn, 1981; Ohmura, 2001). The climatic sensitivity of a glacier not only depends on regional climate variability but also on local topographic effects, which can result in two adjacent glaciers featuring different specific mass-balance responses (Kuhn and others, 1985).

For a temperate glacier, an assumed step-change in climatic conditions would cause an initial mass-balance change followed by a return towards zero values, due to the adaptation of the size of the glacier (surface area) to the new climate (Jóhannesson and others, 1989; Haeberli and Hoelzle, 1995). The observed trend of increasingly negative mass balance over reducing glacier surface areas thus leaves no doubt about the ongoing climatic forcing resulting from the change in climate and possible enhancement mechanisms such as mass-balance/altitude feedback, altered turbulent fluxes due to the size and existence of rock outcrops or changes in the surface albedo. The specific mass-balance data can be compared directly between different glaciers of any size and elevation range. These data series provide a combined hydrological and climatic signal. Glacier contribution to runoff can be calculated very easily by multiplying the specific mass balance with the corresponding glacier area, whereas a climatic interpretation needs to relate the mass changes to a glacier reference extent in order to derive a pure climate signal (cf. Elsberg and others, 2001; WGMS, 2007, and earlier issues).

In order to advance the present mass-balance monitoring, as part of the Global Climate Observing System, it is necessary to continue with the existing data series and to extend the network in respect of the global glacier distribution. Systematic use should be made of remote sensing and geo-informatics for assessing the representativeness of the available in situ observations (e.g. Paul and Haeberli, 2008). Analytical or numerical modelling is needed to quantify the above-mentioned topographic effects as well as to attribute the glacier mass changes to individual meteorological or climate parameters (e.g. Kuhn, 1981; Oerlemans, 2001) and, in combination with measured and reconstructed glacier fluctuations, to compare the present mass changes with the (pre-)industrial variability (e.g. Haeberli and Holzhauser, 2003)

\section{Glacier mass balance and sea-level changes}

Measurements from the mass-balance monitoring network are used to estimate the contribution of glaciers to past, present and future sea-level changes (Kaser and others, 2006 and references therein; Raper and Braithwaite, 2006). These estimates are hampered by the fact that: (a) no complete detailed inventory of the Earth's glaciers exists; (b) the estimation of the overall ice volume of glaciers contains large uncertainties; (c) the spatial distribution of the available mass-balance series is disproportionate to the global ice 
cover; and (d) the small sample of mass-balance observations is (most probably) not representative for the entire sample of glaciers.

Most of the approaches use the regional ice extents of Dyurgerov and Meier (2005 and earlier versions; mainly based on WGMS, 1989) as a baseline inventory to calculate the overall potential sea-level rise equivalent as well as sealevel changes. A detailed inventory, including information on glacier location, size and altitude extent, is only available for about 70000 glaciers covering about $180000 \mathrm{~km}^{2}$. This corresponds to only $43 \%$ of the approximate total number and $23 \%$ of the overall glacier area based on rough estimates from Meier and Bahr (1996) and Dyurgerov and Meier (2005), respectively. As a further uncertainty factor, the existing inventory contains no information on the proportion of ice below sea level. There are only a few glaciers where thickness measurements have been carried out (so far not compiled by the WGMS). Different approaches exist for estimating the overall ice volume (e.g. Haeberli and Hoelzle, 1995; Bahr and others, 1997), but they all contain a number of uncertainties that could amount to $30-50 \%$ of the total ice volume. The latest assessment report of the Intergovernmental Panel on Climate Change (IPCC) (Solomon and others, 2007) quotes the total area and corresponding potential sea-level rise as $510000-540000 \mathrm{~km}^{2}$ and $150-370 \mathrm{~mm}$, respectively. These estimates, as correctly noted in Solomon and others (2007), do not include ice bodies around the ice sheets in Greenland $\left(70000 \mathrm{~km}^{2}\right.$ based on Weidick and Morrris, 1998) and Antarctica (169000 km² based on Shumskiy, 1969) and, hence, might considerably underestimate the overall potential sea-level rise due to melting glaciers. As shown above, many of the regions with large ice covers, such as the Canadian Arctic, High Mountain Asia, South America and around the two ice sheets, are not represented by an adequate number of long-term mass-balance measurements. Mass-balance programmes require intensive fieldwork and are usually carried out on glaciers that are easy accessible, safe and not too large. Hence, these glaciers are neither representative of the glacier size distribution nor of the elevation distribution of all glaciers, at least when compared with the presented data of about 70000 glaciers with detailed inventory information (the data for an exact comparison are not available).

The current first-order estimates of the contribution from glaciers to past, present and future sea-level changes can only be improved significantly by completing a detailed baseline inventory of the Earth's glaciers as well as a review and enlargement of the available (measured) glacier thickness dataset. This would be needed to scale-up the few in situ series that we have to cover all glaciers. It is hoped that internationally coordinated efforts, such as the European Space Agency-funded GlobGlacier project (Volden, 2007) or the Global Land Ice Measurements from Space initiative (Raup and others, 2007), will make major steps in that direction. Furthermore, it is necessary to continue and extend the present mass-balance network in respect of the global distribution of the ice cover and to make systematic use of remote sensing and geo-informatics to assess the representativeness of the available in situ annual massbalance series (Paul and Haeberli, 2008) as well as of decadal volume changes in ice fields and ice caps that are too large for in situ measurements (e.g. Rignot and others, 2003; Larsen and others, 2007).

\section{CONCLUSIONS AND CONSEQUENCES FOR THE MONITORING OF GLACIERS}

During the six decades of glacier mass-balance observation, the WGMS has compiled a dataset of more than 3400 annual mass-balance measurements from 228 glaciers worldwide. The collection and free availability of these data through a purely scientific collaboration network is a great success and, at the same time, one of the reasons why the present monitoring network is unevenly distributed in comparison with the global ice coverage. The 30 reference glaciers with continuous observation series since 1976 show an accelerated thinning, with mean annual ice losses of $0.14 \mathrm{~m}$ w.e. (1976-85), $0.25 \mathrm{mw}$.e. (1986-95) and $0.58 \mathrm{~m}$ w.e. (1996-2005), which gives a total average icethickness reduction of about $10 \mathrm{~m}$ w.e. The available data from the first three decades indicate strong mass losses as early as the 1940s and 1950s, followed by moderate mass losses until the end of the 1970s. The mass-balance data are widely used by the scientific community and represent one backbone of glacier research. Mass balance is recognized as an essential climate variable within the global climaterelated observing systems and is, in effect, the largest nonsteric contributor to the global sea-level rise at the turn of the century.

In view of the discrepancy between the relevance of glacier mass-balance data and the relatively small set of current long-term observations with a strong bias towards the Northern Hemisphere and Europe, we strongly recommend to:

continue the work on the glaciers with long-term measurements,

resume the interrupted long-term series,

replace vanishing glaciers by starting early with parallel observations on larger or higher-reaching glaciers,

extend the monitoring network to strategically important regions with few or no series,

validate and calibrate the field measurements with the results of geodetic methods (and clearly flag such data series),

make systematic use of remote sensing and geoinformatics for assessment of the representativeness of the field measurements and for (decadal) volume change analysis in mountain ranges lacking such data, and

make the data and related meta-information readily available to the scientific community and the wider public.

The potential dramatic changes as sketched for the 21st century by the IPCC report (Solomon and others, 2007) require critical reflection and a rigorous implementation of the monitoring strategies for glaciers in order to face the challenges of the fast changes in nature and to bridge the gap between historical observation series and the new technologies.

\section{ACKNOWLEDGEMENTS}

We express our gratitude to the National Correspondents, Principal Investigators of the WGMS and all other individuals and institutions for the collection and free exchange of these 
important data over many years. Sincere thanks go to the field scientists and programme managers of the long-term data series: without their commitment to maintain the observation series through politically and financially difficult times, many of the current insights would not have been possible. We thank F. Paul for thoughtful remarks on a first draft of the manuscript, the two reviewers for constructive feedback, the scientific editor for providing guidance towards the final paper, and I. Woodhatch for polishing the English. This study has been mainly funded by the Swiss National Science Foundation and the Swiss Federal Office for the Environment.

\section{REFERENCES}

Ageta, Y. and K. Fujita. 1996. Characteristics of mass balance of summer-accumulation type glaciers in the Himalayas and Tibetan Plateau. Z. Gletscherkd. Glazialgeol., 32, 61-65.

Andreassen, L.M., H. Elverøy, B. Kjøllmoen, R.V. Engeset and N. Haakensen. 2005. Glacier mass-balance and length variation in Norway. Ann. Glaciol., 42, 317-325.

Arendt, A.A., K.A. Echelmeyer, W.D. Harrison, C.S. Lingle and V.B. Valentine. 2002. Rapid wastage of Alaska glaciers and their contribution to rising sea level. Science, 297(5580), 382-386.

Bahr, D.B., M.F. Meier and S.D. Peckham. 1997. The physical basis of glacier volume-area scaling. J. Geophys. Res., 102(B9), 20,355-20,362.

Bauder, A., M. Funk and M. Huss. 2007. Ice-volume changes of selected glaciers in the Swiss Alps since the end of the 19th century. Ann. Glaciol., 46, 145-149.

Berthier, E., Y. Arnaud, R. Kumar, S. Ahmad, P. Wagnon and P. Chevallier. 2007. Remote sensing estimates of glacier mass balances in the Himachal Pradesh (Western Himalaya, India). Remote Sens. Environ., 108(3), 327-338.

Braithwaite, R.J. 2002. Glacier mass balance: the first 50 years of international monitoring. Progr. Phys. Geogr., 26(1), 76-95.

Braun, L.N., M. Weber and M. Schulz. 2000. Consequences of climate change for runoff from Alpine regions. Ann. Glaciol., 31, 19-25.

Casassa, G. and 6 others. 2007. Current status of Andean glaciers. Global Planet. Change, 59(1-4), 1-9.

Chinn, T.J.H. 1985. Structure and equilibrium of the Dry Valleys glaciers. NZ Antarct. Rec., 6, 73-88.

Chinn, T.J. 2001. Distribution of the glacial water resources of New Zealand. J. Hydrol. (NZ), 40(2), 139-187.

Cogley, J.G. 1999. Effective sample size for glacier mass balance. Geogr. Ann., 81A(4), 497-507.

Cogley, J.G. 2005. Mass and energy balances of glaciers and ice sheets. In Anderson, M.G., ed. Encyclopaedia of hydrological sciences. Part 14. Snow and glacier hydrology. New York, Wiley, 2555-2573.

Cogley, J.G. and W.P. Adams. 1998. Mass balance of glaciers other than the ice sheets. J. Glaciol., 44(147), 315-325.

Dyurgerov, M. 2002. Glacier mass balance and regime: data of measurements and analysis. Boulder, CO, University of Colorado. Institute of Arctic and Alpine Research. (INSTAAR Occasional Paper 55.)

Dyurgerov, M.B. and J.D. Dwyer. 2001. The steepening of glacier mass balance gradients with Northern Hemisphere warming. Z. Gletscherkd. Glazialgeol., 36, 107-118.

Dyurgerov, M.B. and M.F. Meier. 1999. Analysis of winter and summer glacier mass balances. Geogr. Ann., 81A(4), 541-554.

Dyurgerov, M.B. and M.F. Meier. 2005. Glaciers and the changing Earth system: a 2004 snapshot. 58. Boulder, CO, University of Colorado. Institute of Arctic and Alpine Research. INSTAAR Occasional Paper

Elsberg, D.H., W.D. Harrison, K.A. Echelmeyer and R.M. Krimmel. 2001. Quantifying the effects of climate and surface change on glacier mass balance. J. Glaciol., 47(159), 649-658.
Fountain, A.G. and A. Vecchia. 1999. How many stakes are required to measure the mass balance of a glacier? Geogr. Ann., 81A $(4), 563-573$.

Francou, B., M. Vuille, P. Wagnon, J. Mendoza and J.E. Sicart. 2003. Tropical climate change recorded by a glacier in the central Andes during the last decades of the twentieth century: Chacaltaya, Bolivia, $16^{\circ} \mathrm{S}$. J. Geophys. Res., 108(D5), 4154. (10.1029/2002JD002959.)

Funk, M., R. Morelli and W. Stahel. 1997. Mass balance of Griesgletscher 1961-1994: different methods of determination. Z. Gletscherkd. Glazialgeol., 33(1), 41-55.

Global Climate Observing System (GCOS). 2003. The second report on the adequacy of the global observing systems for climate in support of the UNFCCC. GCOS-82. Geneva. World Meteorological Organization (WMO TD 1143)

Global Climate Observing System (GCOS). 2004. Implementation plan for the global observing system for climate in support of the UNFCCC. GCOS-92. Geneva. World Meteorological Organization (WMO TD 1219)

Grove, J.M. 2004. Little ice ages: ancient and modern. Second edition. London and New York, Routledge.

Haeberli, W. 2004. Glaciers and ice caps: historical background and strategies of worldwide monitoring. In Bamber, J.L. and A.J. Payne, eds. Mass balance of the cryosphere. Cambridge, Cambridge University Press, 559-578.

Haeberli, W. and C. Burn. 2002. Natural hazards in forests: glacier and permafrost effects as related to climate change. In Sidle, R.C., ed. Environmental change and geomorphic hazards in forests. New York, etc., CABI Publishing, 167-202.

Haeberli, W. and M. Hoelzle. 1995. Application of inventory data for estimating characteristics of and regional climate-change effects on mountain glaciers: a pilot study with the European Alps. Ann. Glaciol., 21, 206-212.

Haeberli, W. and H. Holzhauser. 2003. Alpine glacier mass changes during the past two millennia. PAGES News, 11(1), 13-15.

Haeberli, W., J. Cihlar and R.G. Barry. 2000. Glacier monitoring within the Global Climate Observing System. Ann. Glaciol., 31, 241-246.

Hock, R. and H. Jensen. 1999. Application of kriging interpolation for glacier mass balance computations. Geogr. Ann., 81A(4), 611-619.

Hoelzle, M., W. Haeberli, M. Dischl and W. Peschke. 2003. Secular glacier mass balances derived from cumulative glacier length changes. Global Planet. Change, 36(4), 295-306.

Holmlund, P., P. Jansson and R. Pettersson. 2005. A re-analysis of the 58 year mass-balance record of Storglaciären, Sweden. Ann. Glaciol., 42, 389-394.

Huss, M., A. Bauder, M. Funk and R. Hock. 2008a. Determination of the seasonal mass balance of four Alpine glaciers since 1865 . J. Geophys. Res., 113(F1), F01015. (10.1029/2007JF000803.)

Huss, M., A Bauder and M. Funk. 2008b. Homogenization of longterm mass-balance time series. Ann. Glaciol., 50.

Jansson, P. 1999. Effect of uncertainties in measured variables on the calculated mass balance of Storglaciären. Geogr. Ann., 81A(4), 633-642.

Jóhannesson, T., C. Raymond and E. Waddington. 1989. Time-scale for adjustment of glaciers to changes in mass balance. J. Glaciol., 35(121), 355-369.

Kääb, A. 2007. Glacier volume changes using ASTER optical stereo. A test study in Eastern Svalbard. In Proceedings of the International Geoscience and Remote Sensing Symposium (IGARSS 2007), 23-28 July, 2007. Barcelona, Spain Piscataway, NJ, Institute of Electrical and Electronics Engineers, 3994-3996.

Kääb, A. 2008. Glacier volume changes using ASTER satellite stereo and ICESat GLAS laser altimetry. A test study on Edgeøya, Eastern Svalbard. IEEE Trans. Geosci. Remote Sens., 46(10), 2823-2830.

Karlén, W. 1965. Ablation i sprickområden. In Pytte, R. and G. Østrem, eds. Glacio-hydrologiske undersökelser $i$ Norge 
1964. Oslo, Norges Vassdrags- og Elektrisitetsvesen, 65-66. (NVE Hydrol. Avd. Medd. 14.)

Kaser, G. and H. Osmaston. 2002. Tropical glaciers. Cambridge, etc., Cambridge University Press.

Kaser, G., M. Munari, B. Noggler, C. Oberschmied and P. Valentini. 1996. Ricerche sul bilancio di massa del Ghiacciaio di Fontana Bianca (Weissbrunnferner) nel Gruppo Ortles-Cevedale. Geogr. Fís. Din. Quat., 18(2), 277-280.

Kaser, G., J.G. Cogley, M.B. Dyurgerov, M.F. Meier and A. Ohmura. 2006. Mass balance of glaciers and ice caps: consensus estimates for 1961-2004. Geophys. Res. Lett., 33(19), L19501. (10.1029/2006GL027511.)

Kotlyakov, V.M., ed. 2006. Oledenenie Severnoj i Central'noj Evrazii v Sovremennuju epochu [Glaciation in north and central Eurasia at present time]. Moscow, Nauka. [In Russian with English summary.]

Krimmel, R.M. 1999. Analysis of difference between direct and geodetic mass balance measurements at South Cascade Glacier, Washington. Geogr. Ann., 81A(4), 653-658.

Kuhn, M. 1981. Climate and glaciers. IAHS Publ. 131 (Symposium at Canberra 1979 - Sea Level, Ice and Climatic Change), 3-20.

Kuhn, M., G. Markl, G. Kaser, U. Nickus, F. Obleitner and H. Schneider. 1985. Fluctuations of climate and mass balance: different responses of two adjacent glaciers. Z. Gletscherkd. Glazialgeol., 21, 409-416.

Kuhn, M., E. Dreiseitl, S. Hofinger, G. Markl, N. Span and G. Kaser. 1999. Measurements and models of the mass balance of Hintereisferner. Geogr. Ann., 81A(4), 659-670.

Larsen, C.F., R.J. Motyka, A.A. Arendt, K.A. Echelmeyer and P.E. Geissler. 2007. Glacier changes in southeast Alaska and northwest British Columbia and contribution to sea level rise. J. Geophys. Res., 112(F1), F01007. (10.1029/2006JF000586.)

Letréguilly, A. and L. Reynaud. 1990. Space and time distribution of glacier mass-balance in the Northern Hemisphere. Arct. Alp. Res., 22(1), 43-50.

Lliboutry, L. 1974. Multivariate statistical analysis of glacier annual balances. J. Glaciol., 13(69), 371-392.

Meier, M.F. and D.B. Bahr. 1996. Counting glaciers: use of scaling methods to estimate the number and size distribution of glaciers of the world. CRREL Spec. Rep. 96-27. 89-94.

Meier, M.F. and 7 others. 2007. Glaciers dominate eustatic sealevel rise in the 21st century. Science, 317(5841), 1064-1067.

Mercanton, P.L., ed. 1916. Vermessungen am Rhonegletscher/ Mensuration au glacier du Rhône: 1874-1915. Neue Denkschr. Schweiz. Naturforsch. Ges. 52.

Molnia, B.F. 2007. Late nineteenth to early twenty-first century behavior of Alaskan glaciers as indicators of changing regional climate. Global Planet. Change, 56(1-2), 23-56.

Nakawo, M. and B. Rana. 1999. Estimate of ablation rate of glacier ice under a supraglacial debris layer. Geogr. Ann., 81A(4), 695-701.

Nakawo, M., C.F. Raymond and A. Fountain, eds. 2000. IAHS Publ. 264 (Workshop at Seattle 2000 - Debris-Covered Glaciers).

Oerlemans, J. 2001. Glaciers and climate change. Lisse, etc., A.A. Balkema.

Oerlemans, J. and J.P.F. Fortuin. 1992. Sensitivity of glaciers and small ice caps to greenhouse warming. Science, 258(5079), 115-117.

Ohmura, A. 2001. Physical basis for the temperature-based meltindex method. J. Appl. Meteorol., 40(4), 753-761.

Ohmura, A. 2004. Cryosphere during the twentieth century. In Sparling, J. Y. and C.J. Hawkesworth, eds. The state of the planet: frontiers and challenges in geophysics. Washington DC, American Geophysical Union, 239-257.

Ohmura, A. 2006. Changes in mountain glaciers and ice caps during the 20th century. Ann. Glaciol., 43, 361-368.

Ohmura, A., P. Kasser and M. Funk. 1992. Climate at the equilibrium line of glaciers. J. Glaciol., 38(130), 397-411.

$\mathrm{O}^{\prime}$ Neel, S., W.T. Pfeffer, R. Krimmel and M. Meier. 2005. Evolving force balance at Columbia Glacier, Alaska, during its rapid retreat. J. Geophys. Res., 110(F3), F03012. (10.1029/ 2005JF000292.)

Østrem, G. and M. Brugman. 1991. Glacier mass-balance measurements. A manual for field and office work. Saskatoon, Sask., Environment Canada. National Hydrology Research Institute. (NHRI Science Report 4.)

Østrem, G. and N. Haakensen. 1999. Map comparison or traditional mass-balance measurements: which method is better? Geogr. Ann., 81A(4), 703-711.

Østrem, G. and A. Stanley, eds. 1969. Glacier mass balance measurements: a manual for field and office work. Ottawa, Ont., Department of Energy, Mines and Resources; Oslo, Norwegian Water Resources and Electricity Board.

Paul, F. and W. Haeberli. 2008. Spatial variability of glacier elevation changes in the Swiss Alps obtained from two digital elevation models. Geophys. Res. Lett. 35(21). (10.1029/ 2008GL034718.) L21502

Rabus, B.T. and K.A. Echelmeyer. 1998. The mass balance of McCall Glacier, Brooks Range, Alaska, U.S.A.; its regional relevance and implications for climate change in the Arctic. J. Glaciol., 44 (147), 333-351.

Raper, S.C.B. and R.J. Braithwaite. 2006. Low sea level rise projections from mountain glaciers and icecaps under global warming. Nature, 439(7074), 311-313.

Raup, B. and 11 others. 2007. Remote sensing and GIS technology in the Global Land Ice Measurements from Space (GLIMS) Project. Comput. Geosci., 33(1), 104-125.

Rignot, E., A. Rivera and G. Casassa. 2003. Contribution of the Patagonian icefields of South America to sea level rise. Science, 302(5644), 434-437.

Schiefer, E., B. Menounos and R. Wheate. 2007. Recent volume loss of British Columbian glaciers, Canada. Geophys. Res. Lett. 34(16), L16503. (10.1029/2007GL030780.)

Schöner, W., I. Auer and R. Böhm. 2000. Climate variability and glacier reaction in the Austrian eastern Alps. Ann. Glaciol., 31, $31-38$.

Shumskiy, P.A. 1964. Principles of structural glaciology. New York, Dover Publications.

Shumskiy, P.A. 1969. Oledenemie [Glaciation]. In Tolstiikov, E.I., ed. Atlas Antarktiki II [Atlas of Antarctica, vol. II]. Leningrad, Gidrometeoizdat, 367-400. [In Russian]

Solomon, S. and 7 others, eds. 2007. Climate change 2007: the physical science basis. Contribution of Working Group I to the Fourth Assessment Report of the Intergovernmental Panel on Climate Change. Cambridge, etc., Cambridge University Press.

Volden, E. 2007. ESA's GlobGlacier project. Ice Climate News, 9, 5 .

Weidick, A. and E. Morris. 1998. Local glaciers surrounding the continental ice sheets. In Haeberli, W., M. Hoelzle and S. Suter, eds. Into the second century of worldwide glacier monitoring: prospects and strategies. Paris, UNESCO Publishing, 197-207. (Studies and Reports in Hydrology 56.)

World Glacier Monitoring Service (WGMS). 1989. World glacier inventory - status 1988, ed. Haeberli, W., H. Bösch, K. Scherler, G. Østrem and C. Wallén. IAHS (ICSI)/UNEP/UNESCO, World Glacier Monitoring Service, Zürich.

WGMS. 2007. Glacier Mass Balance Bulletin No. 9 (2004-2005), ed. Haeberli, W., M. Zemp and M. Hoelzle. ICSU (FAGS)/IUGG (IACS)/UNEP/UNESCO/WMO, World Glacier Monitoring Service, Zürich

WGMS. 2008a Fluctuations of glaciers 2000-2005 (Vol. IX), ed. Haeberli, W., M. Zemp, A Kääb, F. Paul and M. Hoelzle. ICSU (FAGS)IUGG (IACS)/UNEP/UNESCO/WMO, World Glacier Monitoring Service, Zürich.

WGMS, 2008b Global glacier changes: facts and figures, ed. Zemp, M., I. Roer, A. Kaab, M. Hoelzle, F. Paul and W. Haerberli. UNEP, World Glacier Monitoring Service, Zürich.

Zemp, M., W. Haeberli, M. Hoelzle and F. Paul. 2007a. Glacier fluctuations in the European Alps 1850-2000: an overview and 
spatio-temporal analysis of available data. In Orlove, B., E. Wiegandt and B.H. Luckman, eds. Darkening peaks: glacier retreat, science, and society. Berkeley, CA, University of California Press.
Zemp, M. and 23 others. 2007b. Glaciers and ice caps. Part I: Global overview and outlook. Part II: Glacier changes around the world. In Eamer, J., ed. Global outlook for ice and snow. Nairobi, United Nations Environment Programme.

\section{APPENDIX}

'Reference' mass-balance programmes. The 30 glaciers with ongoing, continuous and long-term mass-balance series since 1976 are listed with country code (PU), WGMS database ID, coordinates (latitude/longitude), first and last observation years as well as number of massbalance surveys. In addition, the table lists the last reported area (in $\mathrm{km}^{2}$ ), the equilibrium-line altitude (ELA0 in $\mathrm{m}$ a.s.l.) and accumulationarea ratio (AAR0 in \%) for steady-state conditions as calculated from the linear regression between ELA/AAR and mass balance (Haeberli and others, 2007), as well as the decadal mean mass changes (in mw.e.) for the decades 1976-85, 1986-95 and 1996-2005. Data from the WGMS

PU Name WGMS ID Latitude Longitude First Last Number Area (year) ELAo AARo 1976-85 1986-95 1996-
obs. obs. of obs. 2005

\begin{tabular}{|c|c|c|c|c|c|c|c|c|c|c|c|c|c|}
\hline AT & Hintereisferner & 491 & 46.80 & 10.77 & 1953 & 2006 & 54 & 7.47 (2005) & 2906 & 66 & -0.195 & -0.861 & -0.873 \\
\hline AT & Kesselwandferner & 507 & 46.84 & 10.79 & 1953 & 2006 & 54 & $3.90(2005)$ & 3118 & 70 & +0.085 & -0.322 & -0.181 \\
\hline AT & Sonnblickkees & 573 & 47.13 & 12.60 & 1959 & 2006 & 48 & 1.39 (2005) & 2740 & 60 & +0.077 & -0.745 & -0.638 \\
\hline AT & Vernagtferner & 489 & 46.88 & 10.82 & 1965 & 2006 & 42 & $8.36(2005)$ & 3082 & 66 & -0.066 & -0.694 & -0.585 \\
\hline $\mathrm{CA}$ & Place & 41 & 50.43 & -122.60 & 1965 & 2006 & 42 & 3.17 (2005) & 2080 & 50 & -0.843 & -1.366 & -0.819 \\
\hline $\mathrm{CH}$ & Gries & 359 & 46.45 & 8.34 & 1962 & 2006 & 45 & $6.19(2001)$ & 2838 & 59 & -0.207 & -0.913 & -0.987 \\
\hline $\mathrm{CH}$ & Silvretta* & 408 & 46.85 & 10.08 & 1960 & 2006 & 47 & $3.01(2003)$ & 2763 & 54 & +0.270 & -0.389 & -0.191 \\
\hline $\mathrm{CL}$ & Echaurren Norte & 1344 & -33.58 & -70.13 & 1976 & 2006 & 31 & $0.40(2000)$ & n.a. & n.a. & -0.033 & -0.310 & -0.331 \\
\hline $\mathrm{CN}$ & Urumqihe S. No. 1 & 853 & 43.08 & 86.82 & 1959 & 2005 & 47 & $1.74(2000)$ & 4025 & 56 & -0.161 & -0.265 & -0.579 \\
\hline FR & Saint Sorlin & 356 & 45.17 & 6.16 & 1957 & 2006 & 50 & $3.00(2000)$ & 2863 & n.a. & +0.143 & -0.882 & -1.460 \\
\hline FR & Sarennes & 357 & 45.12 & 6.14 & 1949 & 2006 & 58 & $0.50(2000)$ & n.a. & n.a. & -0.170 & -1.187 & -1.653 \\
\hline IT & Caresr & 635 & 46.45 & 10.70 & 1967 & 2006 & 40 & $2.83(2005)$ & 3100 & 44 & -0.403 & -1.224 & -1.618 \\
\hline $\mathrm{KZ}$ & Ts. Tuyuksuyskiy & 817 & 43.05 & 77.08 & 1957 & 2006 & 50 & $2.53(2005)$ & 3746 & 52 & -0.731 & -0.466 & -0.340 \\
\hline $\mathrm{NO}$ & Ålfotbreen & 317 & 61.75 & 5.65 & 1963 & 2006 & 44 & $4.50(2005)$ & 1187 & 57 & +0.217 & +1.114 & -0.520 \\
\hline $\mathrm{NO}$ & Austre Brøggerbreen & 292 & 78.88 & 11.83 & 1967 & 2006 & 40 & $6.12(1995)$ & 275 & 53 & -0.449 & -0.367 & -0.620 \\
\hline $\mathrm{NO}$ & Engabreen & 298 & 66.65 & 13.85 & 1970 & 2006 & 37 & 39.55 (2005) & 1172 & 60 & +0.573 & +0.961 & +0.276 \\
\hline $\mathrm{NO}$ & Gråsubreen & 299 & 61.65 & 8.60 & 1962 & 2006 & 45 & $2.25(2005)$ & 2132 & 28 & -0.358 & +0.025 & -0.624 \\
\hline $\mathrm{NO}$ & Hardangerjøkulen & 304 & 60.53 & 7.37 & 1963 & 2006 & 44 & $17.12(2005)$ & 1679 & 68 & -0.074 & +0.800 & -0.154 \\
\hline $\mathrm{NO}$ & Hellstugubreen & 300 & 61.57 & 8.43 & 1962 & 2006 & 45 & $3.03(2005)$ & 1837 & 59 & -0.456 & +0.024 & -0.708 \\
\hline $\mathrm{NO}$ & Midtre Lovénbreen & 291 & 78.88 & 12.07 & 1968 & 2006 & 39 & 5.45 (1999) & 293 & 58 & -0.373 & -0.304 & -0.472 \\
\hline $\mathrm{NO}$ & Nigardsbreen & 290 & 61.72 & 7.13 & 1962 & 2006 & 45 & $47.82(2005)$ & 1565 & 61 & +0.009 & +1.113 & +0.171 \\
\hline $\mathrm{NO}$ & Storbreen & 302 & 61.57 & 8.13 & 1949 & 2006 & 58 & $5.35(2005)$ & 1716 & 59 & -0.355 & +0.179 & -0.610 \\
\hline SE & Storglaciären & 332 & 67.90 & 18.57 & 1946 & 2006 & 61 & $3.21(2005)$ & 1462 & 45 & -0.134 & +0.379 & -0.390 \\
\hline SU & Djankuat & 726 & 43.20 & 42.77 & 1968 & 2006 & 39 & $2.74(2005)$ & 3189 & 56 & -0.120 & +0.180 & -0.137 \\
\hline SU & Leviy Aktru & 794 & 50.08 & 87.72 & 1977 & 2006 & 30 & $5.95(2000)$ & 3160 & 61 & -0.090 & -0.011 & -0.310 \\
\hline SU & Maliy Aktru & 795 & 50.08 & 87.75 & 1962 & 2006 & 45 & $2.73(2000)$ & 3152 & 70 & +0.002 & +0.067 & -0.269 \\
\hline SU & No. 125 (Vodopadniy) & 780 & 50.10 & 87.70 & 1977 & 2006 & 30 & $0.75(2000)$ & 3203 & 68 & -0.074 & +0.020 & -0.246 \\
\hline US & Gulkana & 90 & 63.25 & -145.42 & 1966 & 2005 & 40 & n.a. & 1727 & 63 & -0.157 & -0.540 & -0.880 \\
\hline US & South Cascade & 205 & 48.37 & -121.05 & 1953 & 2006 & 53 & $1.89(2003)$ & 1899 & 53 & -0.592 & -1.150 & -0.695 \\
\hline US & Wolverine & 94 & 60.40 & -148.92 & 1966 & 2004 & 39 & 17.24 (1995) & 1151 & 63 & +0.525 & -0.498 & -0.884 \\
\hline \multicolumn{3}{|c|}{ Mean of $\mathbf{3 0}$ glaciers } & 51.58 & 1.66 & 1962 & 2006 & 45 & $7.25(2003)$ & 2288 & 58 & -0.138 & -0.254 & -0.578 \\
\hline
\end{tabular}

* Recent comparisons with geodetically derived volume changes have shown that the mass-balance measurements of Silvretta have been systematically too positive by several decimetres w.e. per year (Huss and others, 2008a). 